\title{
Reticulocyte haem synthesis in occupational exposure to trinitrotoluene
}

\author{
H SAVOLAINEN, ' R TENHUNEN, ${ }^{2}$ AND H HÄRKÖNEN' \\ From the Institute of Occupational Health, ${ }^{1}$ Helsinki, and Department of Clinical Chemistry, ${ }^{2}$ University of \\ Helsinki, Helsinki, Finland
}

Trinitrotoluene (TNT) causes cataracts in workers even at low exposure levels. ${ }^{1}$ The changes in the lens may be virtually irreversible and be caused by a peroxidative denaturation of the lens fibre protein suggested by the brownish colour of the cataract. ${ }^{2}$ TNT is known to initiate lipid peroxidation through its cyclic reduction and oxidation by mitochondrial nitroreductases giving rise to superoxide anion. ${ }^{3}$

Because of the refined ophthalmological equipment and skills required to detect the changes in the lens we wondered whether a biochemical test could be developed for the effects of absorbed TNT. Our earlier experiment suggested that mitochondrial damage was an initial toxicological effect of TNT in rats. ${ }^{3}$ The rate limiting enzymes of haem synthesis in mammals, $\delta$-aminolaevulinic acid synthase, and haem synthase are of mitochondrial location so that their activity in circulating reticulocytes that still contain mitochondria may be assayed. Subsequently, the acute effects of TNT could be shown in reticulocytes of rats exposed to TNT, ${ }^{4}$ and in the present study we have applied the test to workers with known exposure to TNT.

Received 20 August 1984

Accepted 11 September 1984

\section{Subjects and methods}

Nine workers ( 3 women, 6 men) exposed to TNT in 윽 a factory producing the explosive took part in the study (table 1). Four worked in the packing depart- $\overrightarrow{3}$ ment and five in the synthesis process room. The mean TNT concentration in the process room air $\overrightarrow{0}$ was $0.35 \mathrm{mg} / \mathrm{m}^{3}$ (range $0.31-0.39$ ) and in the pack- o ing department $0 \cdot 10 \mathrm{mg} / \mathrm{m}^{3}$ (range $0 \cdot 02-0 \cdot 19$ ). None of the air samples exceeded the current Finnish hygienic limit level of $0.50 \mathrm{mg} / \mathrm{m}^{3}$.

The clinical state of the participants was unremarkable with the exception of binocular cataracts of varying severity in seven cases (table 1). The opacities were never noted in the central parts of the lens so that they did not interfere with the visual fields. Their demonstration required a maximal pupillary dilatation.' The blood samples $(50 \mathrm{ml})$ were drawn from the cubital vein into heparinised tubes and immediately delivered to the laboratory in an ice bath. The buffy coats were removed by centrifugation and the remaining red cells were suspended in cold $0.9 \% \mathrm{NaCl}$ solution to achieve (2-3) $\times 10^{12}$ cells per litre. The number of reticulocytes was determined and $\delta$-aminolaevulinic acid synthase $ᄋ$ (EC 2.3.1.37) and haem synthase (EC 4.99.1.1) activities were determined. ${ }^{4}$ The results were com-

Table 1 Subjects exposed to trinitrotoluene

\begin{tabular}{|c|c|c|c|c|c|}
\hline Case & Sex & $\begin{array}{l}\text { Age } \\
\text { (years) }\end{array}$ & Task & $\begin{array}{l}\text { Current occupation } \\
\text { (years) }\end{array}$ & Cataract \\
\hline $\begin{array}{l}1 \\
2 \\
3 \\
4 \\
5 \\
6 \\
7 \\
8 \\
9\end{array}$ & $\begin{array}{l}\mathbf{F} \\
\mathbf{F} \\
\mathbf{M} \\
\mathbf{M} \\
\mathbf{M} \\
\mathbf{F} \\
\mathbf{M} \\
\mathbf{M}\end{array}$ & $\begin{array}{l}54 \\
45 \\
58 \\
21 \\
44 \\
28 \\
53 \\
25 \\
36\end{array}$ & $\begin{array}{l}\text { Packing } \\
\text { Packing } \\
\text { Process } \\
\text { Process } \\
\text { Process } \\
\text { Packing } \\
\text { Packing } \\
\text { Process } \\
\text { Process }\end{array}$ & $\begin{array}{r}20 \\
18 \\
18 \\
1 \\
13 \\
19 \\
27 \\
3 \\
7\end{array}$ & $\begin{array}{l}\text { Faint peripheral haze } \\
\text { Continuous equatorial opacity } \\
\text { Spoke like equatorial opacities } \\
\text { None } \\
\text { Faint peripheral haze } \\
\text { Spoke like equatorial opacities } \\
\text { Continuous equatorial opacity } \\
\text { None } \\
\text { Faint peripheral haze }\end{array}$ \\
\hline
\end{tabular}


Table 2 Trinitrotoluene induced effects on reticulocyte haem synthesis

\begin{tabular}{|c|c|c|}
\hline Case & $\begin{array}{l}\delta \text {-Aminolaevulinic acid synthase } \\
\left(p \operatorname{mol} / \mathrm{h} \times 10^{\circ} \text { reticulocytes }\right)\end{array}$ & $\begin{array}{l}\text { Haem synthase } \\
\left(\mathrm{pmol} / \mathrm{h} \times 10^{\circ} \text { reticulocytes }\right)\end{array}$ \\
\hline $\begin{array}{l}1 \\
2 \\
3 \\
4 \\
5 \\
6 \\
7 \\
8 \\
9 \\
\end{array}$ & $\begin{array}{l}0 \cdot 11 \\
0 \cdot 09 \\
0 \cdot 30 \\
0 \cdot 11 \\
0 \cdot 13 \\
0 \cdot 19 \\
0 \cdot 36 \\
0 \cdot 23 \\
0 \cdot 18\end{array}$ & $\begin{array}{r}8 \cdot 6 \\
3 \cdot 2 \\
9 \cdot 7 \\
6 \cdot 6 \\
17 \cdot 1 \\
18 \cdot 6 \\
5 \cdot 6 \\
2 \cdot 7 \\
6 \cdot 4\end{array}$ \\
\hline $\begin{array}{l}\text { Controls: } \\
\text { Mean } \\
\text { 5th percentile }\end{array}$ & $\begin{array}{l}0.50 \\
0.15\end{array}$ & $\begin{array}{r}14.0 \\
6.0\end{array}$ \\
\hline
\end{tabular}

pared with a control range (mean $\pm 2 \mathrm{SD}$ ) of 25 individuals of both sexes with no occupational exposure to chemicals. Statistical evaluation was performed by the Student's $t$ test as modified by Cochran. $^{\mathrm{s}}$

\section{Results and discussion}

The activity of $\delta$-aminolaevulinic acid synthase in the exposed workers was smaller than that of controls $(0 \cdot 19 \pm 0.09, \mathrm{n}=9 v 0.50 \pm 0 \cdot 18, \mathrm{n}=25, \pm$ $\mathrm{SD} ; \mathrm{p}<0.01)$ and four subjects had values below the fifth percentile (mean $-2 \mathrm{SD}$ ) of controls (cases $1,2,4,5$; table 2 ). The mean haem synthase activity of the exposed workers $(8 \cdot 7 \pm 5 \cdot 7, n=9, \pm S D)$ was also somewhat smaller than that of controls $(14 \cdot 0 \pm 4 \cdot 0, n=25, \pm S D ; p<0.05)$. Three subjects had values below the fifth percentile of controls (cases 2, 7, 8; table 2).

None of the exposed workers had clinical anaemia, which may indicate that the haemoglobin synthesis in the bone marrow is not affected. Examination of bone marrow by electron microscopy in experimentally exposed rats failed to show morphological damage of mitochondria. ${ }^{4}$ This might indicate that the TNT induced effects in reticulo- cytes take place in the circulation after the oxygenation of cells in the lungs as molecular oxygen is needed as the acceptor of electrons from the TNT radical. $^{3}$

It is not known whether the changes in the haem synthesis predict the cataract formation which is only found after at least one year in the trade. ${ }^{1}$ The cataracts probably represent cumulative effects of TNT absorption whereas the effects on circulating blood cells must result from a recent exposure as the cells are short lived by comparison with lens components that are maintained the whole life. ${ }^{2}$

\section{References}

' Härkönen H, Kärki M, Lahti A, Savolainen H. Early equatorial cataracts in workers exposed to trinitrotoluene. Am J Ophthalmol 1983;95:807-10.

${ }^{2}$ Hoenders HJ, Bloemendal H. Lens proteins and aging. J Gerontol 1983;38:278-86.

${ }^{3}$ Zitting A, Szumanska G, Nickels J, Savolainen H. Acute toxic effects of trinitrotoluene on rat brain, liver and kidney: role of radical production. Arch Toxicol 1982;51:53-64.

${ }^{4}$ Tenhunen R, Zitting A, Nickels J, Savolainen $H$. Trinitrotoluene-induced effects on rat heme metabolism. Exp Molec Pathol 1984;40:362-6.

${ }^{5}$ Snedecor GW, Cochran WG. Statistical methods. Ames: Iowa State University Press, 1967;114-6. 